\title{
Schopenhauer: crítica da razão e fundamentação do pessimismo
}

\author{
Schopenhauer: Criticism of Reason and \\ Justification of Pessimism
}

\author{
Dax Moraes \\ Doutor em Filosofia \\ Professor adjunto e membro permanente do PPGFIL no \\ Departamento de Filosofia da Universidade Federal do Rio Grande do Norte (UFRN)
}

\section{RESUMO}

O pessimismo pode ser encontrado sob diversas formas na obra de Schopenhauer, embora não haja para o pessimismo em geral uma definição precisa. Ele se mostra antes de tudo como uma espécie de valoração da existência tal como o otimismo, seu contrário. Procuro mostrar que o "pessimismo schopenhaueriano" não deve ser tomado como um pressuposto ou postulado acerca do ser originário, tampouco como mero resultado da experiência de vida. Pelo contrário, trata-se da consequência final da crítica da razão que leva à total refutação de toda e qualquer forma de dogmatismo defensor de uma razão para a existência do mundo. Essa consequência abrange todas as questōes filosóficas, mas, segundo suas premissas epistemológicas, mantém-se como uma avaliação crítica dirigida ao mundo enquanto pensado sob o princípio de razão. Pode-se, então, dizer que esse "pessimismo" não consiste em uma doutrina filosófica sobre um mal metafísico substancial e impessoal.

\section{PALAVRAS-CHAVE}

Pessimismo; Valor; Princípio de razão; Criticismo; Representação.

\begin{abstract}
Pessimism can be recognized in many ways in Schopenhauer's work although it doesn't have a clear definition in general. First of all it appears as a kind of evaluation upon the existence just like it does its opposite - optimism. I try to show that Schopenhauer's "pessimism" is not to be understood neither as a prejudgment or even a postulate about the originary being nor as a mere result of experience of living. It is rather an ultimate consequence of the critique of reason which leads to a full refutation of each and every kind of dogmatic theory on the reason to the existence of the world. Such consequence spreads itself all over philosophic matters, but according to its epistemological starting point it remains as a critical evaluation towards the world so far as it is thought under the principle of reason. So, one can say that Schopenhauer's "pessimism" is not a philosophical doctrine about a substantial nonpersonal and metaphysical evil.
\end{abstract}

\section{KEY WORDS}

Pessimism; Value; Principle of Reason; Criticism; Representation. 
É notável o silêncio sobre o pessimismo em enciclopédias ou dicionários de filosofia, como tema ou como escola. Eventuais exceções a essa constatação, por sua vez, não são tão significativas, sendo-o mais o que aparece recorrentemente vinculado a elas: o nome de Schopenhauer. "Pessimismo" antes parece nomear um juízo de valor emitido acerca de algo e, eventualmente, um epíteto dirigido a quem emite certos juízos negativos. Náo é à toa que o pessimismo apareça recorrentemente subsumido à noção de niilismo enquanto recusa de valor para a existência - o negativo é, acima de tudo, essa recusa. O propósito deste artigo é contextualizar o "pessimismo schopenhaueriano" de modo a náo se perder de vista o que é por ele pensado em vez pura e simplesmente manter em primeiro e único plano seu modo de expressão. Tudo indica que já haja um preconceito com relação ao que seja "pessimismo" para que entáo se tome Schopenhauer como exemplo daquilo a que, a certa altura, o pensador termina sendo reduzido. Contudo, deve-se admitir, o conceito de "pessimismo" não é muito claro e, ao mesmo tempo, raramente analisado no que concerne ao pensamento schopenhaueriano, do qual, ao invés disso, se extraem exemplos enquanto se toma "seu pessimismo" como um pressuposto.

\section{Pessimismo (e otimismo) como valor}

Em um estudo introdutório à compilaçáo de textos oriundos do que recentemente se estabeleceu como "Escola Schopenhaueriana", Fazio nos apresenta um testemunho exemplar do efeito dissonante produzido pela postura schopenhaueriana, reproduzindo uma resenha escrita em I853 por Oxenford ("Iconoclasm in German Philosophy"), anunciada como a primeira publicaçáo sobre Schopenhauer fora da Alemanha:

As tendências dos filósofos alemães modernos, não importando o quanto difiram entre si, são liberais e nobres no mais alto grau. [...] meios importantes para a difusão de ideias nobres, as quais eventualmente tomam a forma de um elevado sistema moral ou têm como objetivo a fundamentação de um sistema científico holístico. Sua palavra de ordem, por estranho que seja o linguajar no qual venha a ser concebida, é sempre "progresso!". São, por isso, ainda que em seu estilo pedante, simpatizantes do espírito da civilização moderna. [...] Por outro lado, enquanto o método de ensino de Schopenhauer é o mais genial, o mais engenhoso [...], a doutrina ensinada é a mais desconfortável, a mais repelente, a mais contrária às aspiraçōes do mundo presente [...]. Tudo aquilo que uma mente liberal observa ansiosa com esperança [...] deveria ser condenado como um sonho vão se algum dia fosse aceita a doutrina de Schopenhauer. Em uma palavra, ele é um declarado pessimista. (Oxenford apud Fazio, 2009, p. 35-36)

O caráter apaixonado da apologia de Lindner em resposta a Oxenford não tira do "jovem discípulo" - então com 33 anos - sua razão ao qualificar como "absolutamente unilateral" (Lindner, 2009, p. 27I, n. 7) semelhante interpretação, que certamente há de contribuir para que Schopenhauer não seja lido, malgrado as qualidades estilísticas de seu texto. Rosset confirma esse fato, sumamente prejudicial a uma adequada aproximação da filosofia schopenhaueriana:

\footnotetext{
1 V. p. ex. o duplo verbete "Otimismo/pessimismo" no Dicionário básico de filosofia: "O pessimismo opõe-se ao otimismo e designa uma atitude ou visão negativa das coisas, esperando sempre que o pior aconteça, ou considerando a realidade adversa, sendo impossível mudar as coisas para melhor. Embora náo designe uma escola filosófica propriamente, alguns filósofos como Schopenhauer tiveram sua doutrina considerada como pessimista" (Japiassú; Marcondes, 1996, p. 203-204; grifo meu). Vale destacar, en passant, o caráter negativo da definiçấo, como se positiva fosse a possibilidade de "mudar as coisas". Por correto que seja considerar a questáo sob esse ponto de vista, uma vez que toda açáo sobre algo é uma efetivação, uma produçáo, portanto uma positivaçâo, considerar o contrário disso como "visão negativa" é bastante sintomático da patente confusão entre os âmbitos metafísico e moral, isto é, do ser e do valer.
} 
O considerável descrédito em que caiu a filosofia de Schopenhauer parece ter como origem principal um patente esquecimento de seus traços maiores, acompanhado, em quase todos os estudos schopenhauerianos, de uma valorização exclusiva dos traços secundários: pessimismo, idealismo estético, moral da compaixão e da renúncia. (Rosset, 1994, p. V-VI)

Eis uma das fortes razóes pelas quais o pessimismo de Schopenhauer carece de devido esclarecimento: não em virtude dele mesmo - o pessimismo como tema, "caractère secondaire” —, mas em vista de uma apropriada contextualização que não impeça a apreensão global de sua filosofia em seus "caractères majeurs". Isso deve significar reconduzir os resultados pessimistas às suas autênticas premissas, sempre convergentes na atitude crítica inspirada em Kant. Eis o que, por diferentes vias, pretende-se expor ao longo de nosso percurso.

Desconsiderado o caráter crítico de seu pensamento, o pessimismo schopenhaueriano é encontrado, à primeira vista, na resposta taxativamente negativa que dá à pergunta: "Viver vale a pena?". De fato, escreve Schopenhauer (2015b, I9, p. 290) "esse querer-a-vida [Lebenwollen] é algo que se entende por si mesmo [sich von selbst versteht], [...] somos Vontade de vida: por isso temos de viver, bem ou mal. [...] esse apego a uma vida, nela mesma de tão pouco valor, é inteiramente a priori e não a posteriori [...]". Não é, portanto, nada acurado afirmar que Schopenhauer "ensina a renúncia à vida", até porque ele bem sabia, e dizia expressamente, que náo se ensina a vontade, nem a querer, tampouco a deixar de querer, além de ter plena consciência do quanto sua doutrina é repelente e até repulsiva a todo aquele que tem em si a vontade afirmada. Quaisquer motivos que se ofereçam à vontade para não mais viver apenas podem esclarecer o intelecto, despertar um sentimento de malestar, contudo, das duas, uma: ou o indivíduo faz mal a si, ressentindo-se ou matando-se, ou dá as costas à injustiça inerente à existência e segue perseguindo sua crença no melhor. A outra saída - a negação da vontade por ela mesma — é um caso de exceção. Sendo assim, Schopenhauer descreve a condição geral da existência e aduz o porquê de a vida, do ponto de vista racional, náo valer a pena.

Se, para a vontade, tal como e enquanto se afirma, a vida é o que mais vale, a representaçáo de valor tende a priori a buscar justificativas para o apego, podendo, a posteriori, confrontar essa determinação intrínseca a fatos que a contradizem ou contrariam. Disso decorre que até mesmo valores morais se fundamentam em relaçôes concretas entre agentes. Sobre esse ponto, é necessário mencionar a admissão, por Schopenhauer, de que haja açôes dotadas de valor moral. De modo algum isso contradiz a inexistência de valores em si, absolutos, confirmando-se na carta de Schopenhauer a Becker, de io de dezembro de I844, citada por Cacciola (I994, p. I56), que dá à questão o seguinte esclarecimento:

[...] o seu conceito de ação com valor moral não tem [...] a pretensão de ser um fundamento último. É apenas um ponto de ligação (Anknüpfungspunkt) que lhe permite, diante do fato da existência da moral e do juízo moral, perguntar a que açóes se atribui um valor moral. Isso nada mais é do que um ponto de apoio para o juízo moral, tomado a partir da experiência interna ou externa. Esclarece, a partir daí, o seu método, que é o de tomar como ponto de partida o efetivamente dado, remetendo-o ao conjunto de outros fenômenos ou a um alvo relativamente último para prová-lo. ${ }^{2}$

Logo, o valor universal segundo o qual se julga objetivamente o valor particular das açóes é evidentemente formulado a posteriori mediante a experiência subjetiva. Desse modo, é erigido em uma espécie de juízo formal que pode ser aplicado a priori a açóes possíveis no sentido de se poder afirmar o que é bom e justo, o que é mau e injusto, justificando-se que

2 Cf. Schopenhauer, 20I8, p. I68-I69. A correspondência de Schopenhauer com seus discípulos constitui a mais recente ediçáo crítica das cartas, traduzida para o italiano, organizada e comentada e por Domenico Fazio. 
se louve açóes do primeiro tipo e se despreze açóes do segundo tipo. Esse parâmetro é expresso mediante o que, em cada afirmação do querer, produz dor e sofrimento, a outrem como a si: o egoísmo. Conforme prossegue Cacciola (p. 159), o caráter transcendente das açôes morais não consiste em que sigam valores transcendentes, mas que se dirijam à salvação. ${ }^{3}$ Conforme escreve Schopenhauer ao início do $\$ 22$ de Sobre o fundamento da moral, por boas que sejam as açôes, o bom, como o mau, não são senão "expressôes de uma relação e extraídos da experiência cotidiana", aplicadas "a partir de um ponto de vista relativo e empírico" (Schopenhauer apud Cacciola, 1994, p. 158, n. 62). O interesse de se pôr em relevo essa questão não se restringe à declaraçáo da relatividade dos valores em geral portanto, de sua náo-transcendência —-, mas, sobretudo, constitui premissa para o que se discutirá a seguir: a doutrina do mal no mundo.

Quanto ao valor da vida - questáo a que deveremos retornar em breve —, que na passagem supracitada Schopenhauer afirma existir, embora pequeno, o mesmo será a cada vez relativo ao que se tem em vista em uma vida como algo digno de apego ou náo. A afirmação que diz ter a vida, "nela mesma, táo pouco valor", exige uma dupla elucidação. Em primeiro lugar, a vida "em si" não é ela mesma um absoluto, mas uma aparência da vontade, precisamente do "querer viver" que ontologicamente a precede, sendo a vida um fenômeno relativo àquilo de que é manifestaçâo - aqui, a vida vale menos enquanto é menos real do que a vontade cujos atos faz visíveis. Seu pouco valor, por sua vez, diz respeito (também) justamente a esse caráter como que "derivado", provisório, limitado e determinado segundo tempo, espaço e causalidade. Desse ponto de vista, o fenômeno é julgado como tal e não como mera contraparte de um ser-em-si — o mundo, como tal, é finito, implicando morte e carência, contra os quais cada um luta e se esforça para obter o máximo possível. A Vida - i.e. o mundo em geral como representaçáo - é valorada segundo o "alvo relativamente último", a saber, o mundo como vontade, assim como, em outras ocasiôes, a vida individual é valorada em relação aos demais fenômenos como algo submetido a uma perpétua luta por matéria. Vale observar que, em ambos os casos, vige uma valoraçáo racional, ora sobre o fenômeno em sua universalidade, ora em sua particularidade.

Do ponto de vista da vontade, a vida é o que mais lhe interessa — não a do indivíduo em particular, é certo, mas a Vida em geral como seu meio de expressão e realização. Já do ponto de vista do intelecto - muito embora, na condição de servo da vontade, busque para ela motivos para a insistência do sujeito na existência —, a ponderação racional estrita logo desfaz o sonho de que se possa verdadeiramente contar com uma satisfação derradeira do desejo, o prazer de viver isento de conflitos. Não obstante, a vontade tem em si uma inata "angústia" com relação à morte; mais do que isso, uma angústia da angústia (ou do medo) da morte (Angst Todesangst), referida no capítulo 4I do MVR II, ao passo que, pela reflexão, não se obteria razóes para tal. Dito de outro modo, tanto o apego à vida como o temor à morte são irracionais, ao passo que tanto a infeliz consciência de que se morrerá quanto a conclusáo de que a morte não atinge nosso verdadeiro ser são ambos racionais. No referido capítulo, o temor à morte é apresentado como o avesso da Vontade de viver (die Kehrseite des Willens zum Leben). Embora as traduçôes de Fonseca e Barboza ${ }^{4}$ vertam "Kehrseite" por "reverso", não se pode negligenciar a carga semântica do original, muito enfraquecida no português.

Schopenhauer náo é tanto um filósofo de oposiçôes quanto de correlaçóes, como a apontada unidade "verso-anverso". Encarar o avesso da vontade de viver é encarar a absurda ameaça da morte, obscurecida pelo fato de que a cada vez a vontade é sempre certa de que

\footnotetext{
3 Cf. Schopenhauer, 2018, p. I70.

${ }^{4}$ V. Schopenhauer, 20I4b, p. I53; 20I5b, p. 557. Sobre isso, v. Moraes, 20II, p. 199-200.
} 
vive e viverá; a um só tempo a angústia da morte inspira transcendentalmente um apego absolutamente desnecessário que apenas tem lugar em virtude de estarmos cegos para nosso ser em si, já apegados à sua mera aparência como o mais real. Náo se trata de razóes e consequências, mas, antes, de modos de expressão: o "instinto" pelo qual a vontade "sabe $a$ priori" que, para ela, a vida é certa, manifesta-se como um apego à vida que, à luz da experiência, se reforça na medida em que se adquire uma consciência da mortalidade e um temor à morte; esse temor, por sua vez, de todo irracional, exprime um angustioso apego irrefletido à vida, movendo todo empenho por sua conservação, apego cuja justificação a razão também se empenha em buscar, a mesma razão que, alçando-se ao filosofar, descobre que nada há a temer, reconciliando-se assim com a certeza a priori da vontade; mesmo quando a imaginação inspira um temor ainda maior à morte, contribui ainda mais para o apego. Essa sinergia, em seu fundo, fazendo da certeza de vida e da angústia de morte lados de uma mesma moeda, traduz a dupla perspectiva segundo a qual o ponto de vista da coisa em si e o do fenômeno são indissociáveis, se não na abstração. Negar o valor da Vida é negar o valor de uma unilateralidade, uma atitude até mesmo vã se não estiver dirigida exclusivamente à explicitação, à denúncia e ao esclarecimento acerca dessa unilateralidade.

Não seria o mal "no mundo" um espectro que, em certa medida, assombra apenas aquele que conta com o melhor? Todavia, algo se anuncia pretendendo uma prioridade na tematizaçáo do pessimismo schopenhaueriano, aquilo mesmo a que seus vários comentadores mais frequentemente o remetem: a doutrina do sofrimento no mundo.

\section{Pessimismo cosmológico}

"Pessimismo cosmológico" é uma terminologia que, de improviso, acabo de cunhar enquanto penso como discutir a remissáo do pessimismo à doutrina do sofrimento no mundo sem que essa abordagem se confunda com as que estáo por vir neste artigo, merecendo, por isso, uma denominação específica. ${ }^{5}$ Coerentemente, "pessimismo cosmológico" deve dar conta daquilo que, segundo alguns, deve ser denominado "pessimismo metafísico", mas se trata de um aspecto particular da metafísica, uma disciplina da metaphysica specialis que estuda a ordem do mundo tal como, de acordo com Schopenhauer, se apresenta à nossa representação. Evidentemente fará falta adentrar nesse aspecto antes de refletirmos sobre o que denomino "pessimismo epistemológico", mas tal opção se justifica na medida em que assume o fio condutor mais comumente adotado na literatura especializada. No entanto, a meu ver, esse caminho deve ser tido como uma digressão, muito embora necessária à maioria dos leitores. A seguir, nos caberá submetê-lo às devidas ponderaçôes.

O mencionado fio condutor do argumento sobre o "mal metafísico" consiste em assumir que toda a luta e sofrimento que caracterizam a existência se enraízam na autocontradiçấo

\footnotetext{
5 Não pretendo, com isso, declarar a originalidade da expressão. Além de já se encontrar aplicada a outros pensadores, é possível depreendê-la de certas abordagens da filosofia schopenhaueriana, sobretudo aquelas que entendem sua metafísica como cosmologia. No entanto, devo admitir que, de minha parte, apenas procuro argumentar em torno dessa posição no que concerne ao tema do presente artigo sem pretender, tampouco, comprometer-me com semelhante chave de leitura. Razáo suficiente para isso consiste em que algo como um "pessimismo cosmológico", a meu ver, parece pressupor uma perspectiva realístico-materialista de todo incompatível com a filosofia transcendental de Schopenhauer. Por sua vez, contra-argumentar em torno da pertinência ou náo de uma "cosmologia schopenhaueriana" demandaria um escrito à parte, de maneira que, nesta ocasiáo em que já tanto me estendo, limito-me ao diálogo acerca dos aspectos do pessimismo indicados na literatura. Mais adiante procurarei mostrar, ao menos, que um "pessimismo cosmológico" seria um caminho vão quando se pretende discutir a possibilidade de um "pessimismo metafísico".

6 Para fins de uma melhor compreensão e preenchimento dessa indesejável lacuna, aconselho o leitor a ler, pelo menos, a seção inicial de meu artigo sobre o pessimismo moral de Schopenhauer (Moraes, 20I7a). V. tb. Cacciola, 1994, p. 65-67.
} 
da Vontade. Por ser autocontraditória, a Vontade não apenas se faz visível como Natureza (MVR I, \$27); uma vez afirmada como efetividade, a mesma Vontade, presente por inteiro e veementemente em cada uma de suas aparências, perpetua-se em uma luta de todos contra todos que pode mesmo levar à autodestruiçáo um indivíduo humano, microcosmo da "Vontade cósmica" (MVR I, \$\$6I/69). . A Vontade em si "entra em conflito consigo mesma precisamente por meio dessa veemência, cravando os dentes na própria carne" (Schopenhauer, 20I5a, \$62, p. 388). Eu concordaria plenamente que a nada se aplica melhor a noção de "péssimo" do que à Natureza. Esta não "evolui", apenas se refina. Como podemos constatar, à luz da análise schopenhaueriana, ela piora a cada passo na medida em que as forças em conflito são sempre mais poderosas. Se é na vida animal que a luta da Vontade consigo mesma se faz mais visível, já que a animalidade atende a motivos imediatos, sem travas ou disfarces, não há cálculo, antecipação nem, por isso, tempo para a deliberação de prós e contras, o grau subsequente, a humanidade, é marcado pelo surgimento da maldade, do dano infligido propositadamente, do tormento espiritual e da loucura, da culpa e da retaliação, culminando na injustiça extrema do canibalismo institucionalizado e no suicídio como expressão máxima daquele conflito interno uma vez que invada a consciência individual. Por isso mesmo se justifica, talvez mais do que em qualquer outro caso, falar em um pessimismo "cosmológico", pois a ordem (kosmos) da Natureza consiste em levar a tensão interna do querer ao nível máximo que caracteriza o chamado "pior dos mundos possíveis". No entanto, a seguir veremos, mediante o critério segundo o qual delimito o que caberia chamar "pessimismo metafísico", que o fato de o caráter péssimo da vida se enraizar na essência não faz dessa essência algo transcendentemente mal em si mesmo. O mal pertence, sim, à vida, ao cosmos, à aparência global da Vontade e ao modo pelo qual a Natureza administra sua, por assim dizer, "economia interna". Agora inteiramente diverso seria atribuir o mal em si mesmo ao objeto da metaphysica generalis — o ser em si. Que se denomine esse mal inerente a toda vida, e mesmo sua condição de possibilidade, um mal metafísico, se deve a passagens como a seguinte:

[...] poder-se-ia facilmente tomar uma tal descrição como mera declamação sobre a miséria humana, como frequentes vezes já foi feito, e assim ficaria sujeita à acusação de unilateralidade a partir de fatos particulares. De semelhante suspeita e censura, por conseguinte, está livre nossa demonstração acerca do sofrimento inevitável, enraizado na essência da vida; demonstração perfeitamente fria e filosófica, pois parte do universal e é conduzida a priori. (Schopenhauer, 2015a, \$59, p. 376)

Observe-se que a passagem escolhida não é descritiva, mas conclusiva. Mais do que isso, uma conclusão em que Schopenhauer se defende da precipitada acusaçáo de parcialidade. Além disso, esse trecho torna o que aqui denomino "pessimismo cosmológico" irredutível ao pessimismo antropológico, certamente também encontrável em Schopenhauer enquanto diagnostica a natureza humana. Schopenhauer antes apresenta o mal universal para então tematizar o mal humano como um caso particular que nos diz respeito mais imediatamente no contexto das açóes e interaçôes. À luz do que foi dito no início deste artigo, significa que o autor não pretende estar emitindo um mero juízo de valor sobre a condição de vida no mundo, mas remetê-la a uma elucidação de alcance universal a partir da essência mesma desse fenômeno da vida. Sim, essência da vida — não é a "Vontade" em si mesma em geral (que permanece sempre incognoscível), mas aquela afirmada segundo sua autocontradiçáo que faz do sofrimento mediante o esforço pela autoconservação a essência da vida. Explícito

\footnotetext{
7 Sobre a questáo particular da autocontradição da Vontade no âmbito da filosofia da natureza, ver Moraes (2018), especialmente nas páginas 276-285.
} 
é, porém, no texto citado, que a imparcialidade da conclusão implica que não se trata apenas da condiçáo humana, mas de todo o cosmo, rompendo assim com todo antropocentrismo na medida em que o humano náo difere de todo o resto por essência, mas por acidente até mesmo a gravidade é o fenômeno de uma tensão e, portanto, aparência de um esforço, que, segundo Schopenhauer, encontra-se no fundo de sua hipertrofiada definição de sofrimento (MVR I, \$56). A questão que deve ser posta é, todavia, se o caráter péssimo assim explicitado se refere à coisa mesma ou táo somente às suas configuraçóes finitas, ou seja, se se trata de um mal em si ou apenas relativo ao que vive. Minha resposta a essa questão já deve ser clara para o leitor, mas é cabível trazê-la na palavra do próprio Schopenhauer:

O mundo existe como espelho dessa afirmação, com inúmeros indivíduos no tempo e espaço sem fim, no sofrimento sem fim, entre procriaçáo e morte sem fim. Contudo, de lado algum pode-se elevar um lamento, pois a vontade desempenha a grande tragicomédia arcando com os próprios custos, sendo igualmente espectadora de si mesma. O mundo é precisamente assim porque a vontade, da qual ele é a aparência, é como é, e quer dessa maneira. A justificativa para o sofrimento é o fato de a vontade afirmar-se a si nessa aparência, e esta afirmação é justificada e equilibrada pelo fato de a vontade portar o sofrimento. Aqui já se descortina a uma mirada na justiça eterna e universal [...]. (Schopenhauer, 20I5a, \$60, p. 384; grifo meu)

A justiça eterna consiste nesse equilíbrio que conserva a proporcionalidade global de forças afirmadas e negadas, a harmonia indestrutível e atemporal de uma só Vontade que sempre fecha seus débitos e créditos. A economia geral da Natureza sempre deixa saldo zero, não importa que pareça o contrário, pois tudo aquilo que se tira de outrem — considerado individualmente - , tira-se de si mesmo - considerado universalmente —, pois cada um é uma só Vontade. Se assim não fosse, a tensão terminaria enfim pela preponderância de um polo sobre outro, que se fortaleceria em proporção geométrica, mas o caso é que apenas os indivíduos perdem ou ganham, não sua essência comum. Não é possível neste momento adentrar no tema da negação da Vontade por ela mesma, mas, enquanto discutimos a questão do caráter péssimo da existência, vale destacar que o mal no mundo, ao qual à Vontade em geral é indiferente, consiste em um mal que não atinge senão as aparências, elas mesmas consistindo em seu próprio mal enquanto vontades individuais afirmadas.

Portanto, se considerarmos o mundo como Vontade, ressaltará a harmonia, mas, de acordo com o ponto de vista da representação, vigerá o conflito eterno. Como ambos os pontos de vista são complementares, há uma referência recíproca necessária de ambos, já que se trata do mesmo mundo. Assim, do ponto de vista da representação, o conflito refere-se à essência da Vontade e ao seu desdobramento, que permite a passagem do uno ao múltiplo; e, do ponto de vista da Vontade, há uma referência à multiplicidade fenomênica quando se fala na harmonia da natureza. (Cacciola, 1994, p. 88; grifo meu)

Desse modo, remeter a eterna luta entre indivíduos à essência comum oferece ao mal no mundo uma justificativa metafísica lato sensu, ou cosmológica stricto sensu. Por outro lado, conceber globalmente a harmonia significa reconhecer o equilíbrio de perdas e danos quando se considera essa luta em sua universalidade - pois "a harmonia na natureza seria apenas a visibilidade da unidade do em-si que nela se manifesta" (Cacciola, 1994, p. 65), unidade que, aliás, é incognoscível nela mesma. Ambas as perspectivas são, enquanto perspectivas, indissociáveis e relativas uma à outra, elucidando-se reciprocamente, jamais autorizando uma absolutizaçáo unilateral, justamente o que Schopenhauer buscava evitar, tendo, porém, malogrado exatamente por atribuir todo mal à essência universal quando, a rigor, se referia às manifestaçóes particulares, espaço-temporais dessa essência. Por isso diz Cacciola (I994, p. II4) com absoluta precisão: "Somente como sujeitos do querer é que 
estamos submetidos ao ímpeto dos desejos. Portanto, só objetivada no corpo é que a vontade é fonte de dor e sofrimento. É o modo de conhecer que impóe essa direção subjetiva ao $e m$-si". ${ }^{8} \mathrm{O}$ que é dito na sentença final, por mim destacada, será nosso objeto central mais adiante, apontando justamente para aquilo que pretendo defender como constituindo a fundamentação do pessimismo schopenhaueriano em todas as suas formas. O próprio conflito interno da Vontade só pode ser tomado como seu "caráter essencial tendo em vista o mundo como Representaçáo" (Cacciola, 1994, p. 67). Todavia, feita essa observação, mantenhamo-no tópico presente.

De tudo isso se depreende que o mal pertence em primeiro lugar à ordem física, a partir da qual a metafísica imanente busca uma justificação não transcendente, isto é, no mundo e mediante as experiências interna e externa. O sentido de tal justificação é, em última análise, moral. A noção schopenhaueriana de "justiça eterna", portanto, não tem a pretensão de atribuir o mal a uma instância absoluta, mas de oferecer ao mundo das açôes um esclarecimento para a natureza da vida ética, o que, segundo Schopenhauer, seria impossível se nos mantivéssemos no registro dos fatos físicos. Afinal, na Natureza as coisas são o que são necessariamente e isso deve significar: de nada vale, em última análise, julgá-la moralmente. A moralidade pertence ao âmbito da liberdade, portanto à vontade, não à representação. A vacuidade dos juízos de valor sobre a Natureza parece implodir o próprio pessimismo cosmológico, exceto quando se tem em vista um propósito maior e mais nobre: o estabelecimento da significação moral do sofrimento na existência, a saber, o apelo à negação da vontade. Eis porque a visão péssima é preferivel à visão ótima, esta orientando à insistência no erro e à perpetuação do sofrimento. Em acréscimo, semelhante doutrina, antes de recomendar o puro e simples desprezo pela vida, aconselha-nos a benevolência incondicional para com tudo o que vive. Por fim, ou em primeiro lugar, do mesmo modo que se responsabiliza cada indivíduo por sua própria existência, irredutível à causalidade natural, se responsabiliza cada um por todo sofrimento que sua existência necessariamente acarreta. Assim pode emergir como princípio que toda ação deve ser valorada na proporção do que nela se encontra de egoísmo prático, caso particular e moralmente condenável do inevitável egoísmo natural cosmologicamente justificado. Isso se confirma a partir das páginas iniciais do capítulo 47 do MVR II, "Sobre a ética".

Desprezando-se, no entanto, o fato do mal no mundo, a tradição otimista apelou a uma fantasiosa esfera transcendente na qual se encontraria um perene Bem Absoluto. Trata-se de uma ilusão da qual Schopenhauer quer nos desiludir, do fundamento de uma esperança da qual Schopenhauer, chamando-nos para a realidade brutal, pretende nos desvencilhar. Por isso escreve ao fim do $\$ 59$ do MVR I: “o otimismo, caso não seja o discurso vazio de pessoas cuja testa obtusa é preenchida por meras palavras, apresenta-se como um modo de pensamento não apenas absurdo, mas realmente impiedoso: um escárnio amargo acerca dos sofrimentos inomináveis da humanidade" (Schopenhauer, 2015a, p. 378).

\footnotetext{
8 Cf. Schopenhauer (2015a, \$18, p. II8), segundo suas próprias palavras: "Todo ato verdadeiro, autêntico, imediato da vontade é também simultânea e imediatamente ato do corpo que aparece: e, em correspondência, toda ação sobre o corpo é também simultânea e imediatamente açẫo sobre a vontade: que enquanto tal se chama dor, caso a contrarie, ou bem-estar, prazer, caso lhe seja conforme." Significa dizer que todo sofrimento (bem como todo deleite) consiste em modo do querer/não-querer próprio a uma vontade objetivada, portanto, no tempo e no espaço, corporificada como um fenômeno sujeito à causalidade. Náo que a vontade sofra ou produza efeito, mas que imediatamente se desagrade ou agrade mediante os efeitos de objetos sofridos pelo corpo ou pelo intelecto. Como ressalta Schopenhauer logo a seguir, isto náo significa que dor e prazer sejam representaçôes. Náo se trata de dizer que as afecçôes sejam representaçôes, mas que tais afecçôes se manifestam como atos de vontade mediante representaçóes, de maneira que a capacidade para agrado e desagrado é proporcional à capacidade representacional e nesse sentido varia segundo a constituiçâo do sistema nervoso e a inteligência.
} 
Nesse sentido, Schopenhauer não teria, segundo Rosset (1994, p. 53) o propósito de nos dar "explicaçôes", "mas de denunciar as explicações". Em última instância, porém, o mal em si mesmo não teria justificativa, pois seu "por quê", como todo e qualquer porquê, pertence à forma do conhecimento, é dependente da causalidade, jamais atribuível à coisa em si. Isso nos leva, sim, à perda do consolo que Schopenhauer procura oferecer à racionalidade regida pelo princípio do fundamento - afinal, a coisa em si, ela mesma, não pode ser legitimamente dita causa do mal; quando muito, aquilo cuja expressão se faz malefício a todo e qualquer indivíduo. Desta feita, o pessimismo cosmológico é um elemento ineludível da Ética, âmbito em que ganha sua plena funcionalidade, mas que, nele mesmo, é sem valor: afirmá-lo apenas em virtude de si mesmo seria, sim, uma unilateralidade vazia, um mero lamento, um "niilismo". Clément Rosset dedica-se a enfatizar, por essa via, a visão do absurdo - da qual o pessimismo schopenhaueriano seria apenas um "aspecto superficial" (Ibid., p. 65) —, vendo antes, como marca pessimista, precisamente essa falta de causalidade. Por essa via, Rosset se mostra mais fiel ao fundo original de todo o pensamento schopenhaueriano quando diz, por exemplo: "O Querer é o Universo, não a causa do Universo. Em si, ele é cego e inexplicável, e reside precisamente aí a razão do mundo absurdo." (Ibid., p. 52; v. p. 66-67); "Schopenhauer investigava uma causa para o mal em vez da ausência de mal. Mas a ideia de um mal causado é contraditória, pois o mal consiste na ausência de causa." (Ibid., p. 8I). Por isso ele pode dizer: "A dor deve ser interpretada como uma experiência da contingência. Todos os textos schopenhauerianos consagrados à descrição dos males de que sofre a humanidade devem ser lidos nesse contexto" (Ibid., p. I8). Logo, é em vista da proposta moral que Schopenhauer se esmera em encontrar, para o sofrimento, uma saída - uma saída, sempre, para nós. Talvez seja esta a motivação para que, nas palavras de Rosset (Ibid., p. 52), a causalidade seja uma tentação eterna, poderosa a ponto de "incitar até mesmo o leitor de Schopenhauer a encontrar no Querer uma causa". Afinal, apenas mediante a causalidade, diz Schopenhauer, pode haver entendimento. É necessário entender o que significa ser-ético, ser ético deve ser em alguma medida possivel, e Schopenhauer enumera os testemunhos que o confirmam.

Ainda sobre a conclusão de que o sofrimento advém de uma "experiência da contingência", acrescenta-se à relatividade do mal ao mundo como representação o fato de que todo sofrimento se encontra em proporção a outras contingências, desta vez particulares: o grau de objetivação - proporcional à constituição do sistema nervoso - e a constituição individual do espírito, ou caráter. Sobre isso também o próprio Schopenhauer oferece amplo material, útil especialmente a quem se atém às reiteradas afirmaçôes de que o mal, sendo essencial à vida, é distribuído por todas as espécies — sim, mas em medidas muito distintas e até mesmo incomensuráveis. Isso porque não se trata apenas de o esforço constituir o sofrimento na medida em que envolve a superação de um obstáculo para a afirmação do próprio querer individual, de esse esforço ter início em virtude do sentimento intimo e muitas vezes inconsciente de uma carência incontornável, constitutiva de um querer infinito corporificado em um ser finito, de toda conquista ser mero ponto de partida para nova carência e reinício de todo o círculo... (Schopenhauer, 2015a, \$56, p. 357-358) Trata-se, sobretudo, da capacidade de sofrer, não somente física, mas também mental - sobretudo mental. A existência inorgânica e a vida vegetal são ditas absolutamente cegas e inconscientes, seus esforços não envolvem lamentação e sua luta consiste em um impulso insensível. Os animais, de acordo com o desenvolvimento de seu sistema nervoso, sofrem em demasia, mas apenas no presente. No final do $\$ 56$ do MVR I, Schopenhauer (2015a, p. 359) chega a recorrer a uma tela de Tischbein para mostrar que um devastador sofrimento moral humano, posto em analogia com uma situação corriqueiramente vivenciada pelos animais, "se torna possível apenas pela distinção do conhecimento, pela claridade da consciência", razão 
pela qual é com o concurso da consciência humana que o mal alcança sua máxima potência, seja do ponto de vista ativo, seja do passivo. O humano, por sua vez, vivendo quase exclusivamente nas ficções de passado e futuro, sofre principalmente pelo que poderia ou não "deveria" ter sido e pelo que pode ou não vir a ser. A dor moral é alucinante e incomensurável, é capaz de projetar os piores suplícios infernais sobre a face da terra, de maneira que, como o próprio Schopenhauer observa, é comum que pessoas inflijam a seus próprios corpos males imediatos, físicos, que possam desviar-lhes a atenção dos tormentos do espírito. Nesse sentido, a ausência de abstraçóes sobre o que poderia ser diferente do que é, por si só, reduz o sofrimento.

[...] vale para os eventos interiores o que vale para os exteriores, a saber, não há para nós consolo mais eficaz que a completa certeza de uma necessidade inexorável. Um mal que nos sobreveio náo é mais atormentador do que o pensamento nas circunstâncias que poderiam tê-lo evitado [...]. (Schopenhauer, 20I5a, \$55, p. 354)

Eis de que maneira a consideração da necessidade faz implodir qualquer juízo de valor sobre a Natureza. Um interesse especial nessa passagem que anuncia a importância de se adquirir um conhecimento adequado acerca do próprio caráter consiste em que lança uma luz adicional sobre o próprio sentido da visão "pessimista": trazer de volta à realidade 9 , para longe dos sonhos otimistas de melhora ou de que as coisas possam se dar diferentemente, de que somos imbuídos de algum poder que nos permita fazer da vida o que bem entendamos. Ora - pode-se dizer —, a negação dessas possibilidades é uma negação pessimista! Náo seria antes - pode-se responder com uma pergunta - admitir os fatos em vez de, como faria um pessimista, esperar pelo pior? O pior, no fundo, já se sabe, e está bem aí, por toda parte. Eis em que sentido o pessimismo não é uma recusa pura e simples do otimismo, mas também uma espera, só que uma espera pelo pior, um desesperar. Se em algum momento pessimismo e realismo nos parecem o mesmo é porque pressupomos que as coisas tenham de melhorar e não aceitamos a negativa. Ou seja, o sofrimento é um fato necessário — guardadas as devidas ressalvas, pois a necessidade pertence às representaçôes —, metafisicamente elucidado, mas sucumbir a ele é sempre contingente - afinal, está em relação com o caráter da vontade e com as circunstância a que é submetido. A avaliação da filosofia schopenhaueriana quanto a isso diz mais sobre nós do que sobre ela, uma vez que pressupóe nossos pressupostos acerca do mundo. Clément Rosset nos dá disso a seguinte imagem:

[...] poderíamos perfeitamente imaginar um mundo completamente destituído de finalidade, mas cuja ausência de finalidade não fosse em si um objeto de espanto. Em tal mundo, nada imporia ao espírito a ideia de finalidade, de modo que não se teria nenhuma oportunidade para se tomar consciência de sua ausência. Mas semelhante mundo não é o que conhecemos, onde, pelo contrário, tudo conspira sugerindo aquela ideia. (Rosset, 1994, p. 70)

Em síntese, o mal se enraíza no próprio espírito sofredor, no subjetivo, ou, pelo menos, aí é que se faz verdadeira e positivamente sentir como tal. É para o sujeito que experiência interna e experiência externa têm lugar, seja de que qualidade forem, pois, afinal, que se haverá de dizer do mundo para além dessas experiências? O mundo que conhecemos - é, afinal, o mundo que podemos conhecer, a que somos determinados a conhecer - é conhecido à luz da lei da causalidade, a qual, para todo efeito, exige uma causa, a qual também nos dá, a nós humanos, a ilusão de podermos exercer efeitos no mundo por "vontade própria", por livre-arbítrio. Enfim, paradoxalmente, a causalidade nos dá a conhecer todo o real objetivo

9 V. Schopenhauer, 2015a, \$57, p. 365. 
e, ao mesmo tempo, inspira em nós as mais extravagantes fantasias subjetivas, entre elas causas para o mal ou para sua supressão, mas a própria existência é, segundo Schopenhauer, não causada. Não à toa sentencia Rosset (1994, p. 85): "A humanidade situou mal sua inquietude". O mal não reside no esforço frustrado, condenado ao fracasso, mas no representar-se o pelo-quê esforçar-se. Acrescento de minha parte: Não será isso o que pretende mostrar a moral da renúncia? Não que o mundo seja mau, mas que o mal se produz na medida do esforço pelo próprio bem?... Por isso mesmo o padecimento assume infinitos graus entre os seres humanos. De um longo parágrafo do $\$ 57$ do MVR I, a fim de não me delongar mais, já tendo ido tão longe em atenção à aparente confusão generalizada em torno do tema, destaco, ao término desta seção, apenas o seguinte: $\mathrm{O}$ sofrimento de qualquer indivíduo, bem como seu bem-estar — já que são sempre relativos entre si — "não seriam determinados pelo exterior, mas precisamente só por meio daquela medida, daquela disposiçáo [própria a cada um], a qual, devido a condiçóes físicas, poderia vez ou outra, em diferentes tempos, experimentar um acréscimo ou decréscimo, porém, no todo, permaneceria a mesma" (Schopenhauer, 20I5a, p. 366), ou seja, exatamente como no caso da harmonia da Vontade atemporal, de que o homem é o microcosmo.

\section{Pessimismo metafísico}

Será desprezível o que observa Fazio (20I4, p. 95), a saber, que nenhum dos discipulos diretos de Schopenhauer "interpreta o seu pensamento em chave pessimista", o que, no entanto, só terá sido feito após sua morte? ${ }^{10}$ Retomando a questáo já levantada de início, é realmente um forte indício de pessimismo a negação do valor da existência, mas haverá qualquer valor a priori? Schopenhauer o nega. Lê-se no $\$ 8$ da monografia Sobre o fundamento da moral:

Todo valor é a apreciação de uma coisa em comparação com uma outra, portanto um conceito comparativo e por isso relativo. É esta relatividade que constitui mesmo a essência do conceito de valor. [...] Um valor absoluto, incomparável, incondicionado, tal como deve ser a dignidade [do homem, em referência a Kant], é, por isso, como muitas coisas na filosofia, uma tarefa posta por palavras para um pensamento que náo se pode sequer pensar [...]. (Schopenhauer, 200Ia, p. 83)

Uma vez que se concorde que pessimismo e otimismo sejam valoraçôes, decorre imediatamente que um pessimismo ou um otimismo não podem ser metafísicos em sentido forte em uma filosofia como a de Schopenhauer. Para tanto, ele precisaria oferecer um Mal no mínimo transcendental, mas não será todo mal empirico e material, relativo à luta entre indivíduos? O trecho acima oferece duas contribuiçôes: primeiro, que não há semelhante critério absoluto para julgar a existência; segundo, que tal valor, sendo uma questão posta dogmaticamente por palavras, palavras que buscam se referir ao impensável, a algo que não é de modo algum objeto de uma experiência possível, não requer, para ser refutado, um valor contrário. Esta última é uma meditação fundamental sobre o que diz o fim da citação. Uma metafísica "otimista" é aquela dogmática que produz uma entidade sobrenatural - o Bem —, dominantemente personificada e divinizada. O assim chamado "pessimismo" de Schopenhauer não opóe a essa entidade um valor contrário hipostasiado, de maneira que, se fosse "metafísico" em sentido estrito, seria sem objeto, o que é absurdo, e, portanto, pura-

\footnotetext{
${ }^{10}$ Os discípulos diretos pertenceriam à chamada "Escola em sentido estrito", incluindo Frauenstädt e o já citado Becker. Mais sobre isso pode ser encontrado em outros trabalhos de Fazio (2007; 2009; 20I8). Cabe observar que há pontuais exceções para essa apreciação, muito embora a adoçáo do adjetivo "pessimista" náo signifique propriamente o mesmo que "interpretar em chave pessimista".
} 
mente abstrato, igualmente vazio, de nada lhe servindo exemplos empíricos para sua justificação, expediente utilizado, ao contrário, pelos "dogmáticos". Dizer que a Vontade é má em si é como buscar a todo custo um sujeito para um predicado que se considera real "em si”. Dito brevemente, a metafísica imanente julga as aparências enquanto aparências, não autorizando, todavia, a postulação de um mal em si, pois o mal é nele mesmo relativo a nós enquanto seres mundanos. Aqueles que tomam partido do "ótimo" dizem coisas vazias de conteúdo na medida em que não haveria bem positivo na existência - i.e. total satisfação e ausência de esforço —, não cabendo à filosofia crítica opor-lhe um pessimismo sob a forma positiva de uma doutrina, tampouco oferecer paliativos otimistas, mas sim, simplesmente desmascarar-lhes a vacuidade do conteúdo - este seria, conforme a expressão de Malter, um pessimismo critico.

Por isso, a filosofia de Schopenhauer pode, com razão, ser dita "pessimista” apenas se se entende "pessimismo" como um conceito crítico, e isso desde um duplo ponto de vista formal: I. [...] como uma maneira de entender o mundo empírico dado, [...] uma das maneiras pelas quais a razáo reflexiva se volta para a experiência da dor. 2. O conceito de "pessimismo" diz a maneira exata de conceituar racionalmente essa experiência, [ao passo que eudemonismo e otimismo] se referem à maneira falsa de conceituar racionalmente a existência da dor. Pessimismo, por isso, é um conceito de valor: ele fala da compreensáo exata ou falsa da experiência dada concretamente ao homem. [...] mas essa faticidade [da dor] é possivel somente se vige o princípio de razão suficiente. (Malter, 2009, p. 625; grifo meu)

Enfim, a refutação do otimismo metafísico não haverá de deixar senão um lugar vazio, e é desse vazio que nos conta a filosofia de Schopenhauer, bem como do esforço diário da vontade afirmada em preenchê-lo - esforço vão. A frequentemente constatada precariedade da existência mundana levou inúmeros pensadores a buscar um ponto de apoio que a redimisse, e o que faz Schopenhauer é apenas tirá-lo, des-iludindo-nos. Nesse sentido, Malter prossegue dizendo que a culpabilidade da existência e sua nulidade a ser superada também devem ser compreendidas à luz do princípio de razão, de maneira que o "pessimismo", escreve ele entre as devidas aspas, "só concerne ao ser que se encontra submetido ao domínio do princípio de razão e lhe confere seu valor negativo" (p. 626) ${ }^{11}$ Não se nega que, conforme dito acima, o problema do valor se converte no problema mais amplo do niilismo, mas antes se lhe aponta o âmbito próprio de alcance, que não atinge o ser-em-si como tal, exceto seu modo de aparição no intelecto. É sobre a relação vigente entre aquilo que aparece ao sujeito e esse sujeito mesmo que se atribui valor, na medida em que atende ou contraria seu interesse, aqui negativo como positivo no otimismo, sendo o pessimismo não uma doutrina, mas uma atitude - nas palavras de Malter (p. 627), o pessimismo é "crítica do eudemonismo, $[\ldots]$ crítica do otimismo que flui da teodiceia [...] como conduta de vida que assume o valor de um corretivo" e "a atitude genuinamente filosófica nos conflitos da existência temporal". Embora não devamos nos ocupar do niilismo no presente trabalho, a questáo do valor se faz pertinente na medida em que, com a relatividade dos valores, nega-se a dignidade de tudo o que há, não apenas da vida, do mundo, mas inclusive do homem e sua liberdade, bastião da filosofia moderna. O conhecimento mesmo tem um valor instrumental, ao passo que a liberdade, nela mesma, produz indiferentemente o mal

${ }^{11}$ Eu mesmo sugeri outra compreensão da culpabilidade (Moraes, 20I7a, p. 369), à qual tornarei a me referir. Por ora, cabe observar que não há conflito com a posição de Malter aqui expressa, mas complementaridade, pois minha sugestão não parte da compreensão da causa e em que esta reside — a saber: que a existência fática e seus males decorrem do próprio querer — , mas no caráter ontológico da possibilidade de afirmação ou negação da Vontade — a possibilidade de ser ou náo ser em geral. 
e o bem no mundo, pois não se vê, assim como o conhecimento, previamente orientada para um ou outro.

A absoluta liberdade de ser que caracteriza todos os fenômenos da Vontade não traz consigo dignidade alguma, pois toda dignidade é uma atribuição de valor a posteriori como fruto do orgulho da espécie, o pilar central do otimismo metafísico, seja sob sua forma teológica, seja sob sua forma laica na qual persiste. Isso remete diretamente ao erro fundamental das filosofias que elegeram como princípio originário, em lugar da vontade irracional, o intelecto e, por extensão, a alma racional.

Os filósofos anteriores a Kant, com poucas exceçóes, abordaram do lado invertido a explanação do processo de nosso conhecimento. A saber, partiram de uma assim chamada alma, uma entidade [Wesen] cuja natureza íntima e função própria consistiria no pensar e, em verdade, particularmente no pensar abstrato com meros conceitos [...] [Mas, pelo contrário], no processo de conhecimento, o último produto dele, o pensamento abstrato, converteu-se no primeiro e originário, e dessa forma, como disse, aborda-se a coisa do lado invertido. - [...] segundo a minha exposição, o intelecto brota do organismo e por isso da vontade, portanto, sem esta náo poderia existir [...]. (Schopenhauer, 2015b, 22, p. 334-335)

Portanto, possuir uma “alma racional” em nada garante a distinção essencial do homem com relação a todo o resto, náo se podendo, portanto, fundamentar nessa abstraçáo ou nesse acidente qualquer dignidade. O que distingue a espécie humana, por inteligente que seja, é tão somente uma diferença de grau, o grau distinto de objetidade da Vontade manifesta nessa espécie, mero acidente da essência comum a toda existência, uma faculdade especial que se acrescenta à faculdade animal de conhecimento. Se esse é um mal "metafísico", o é apenas na medida em que o ser humano se vê frustrado ao ter de admitir sua pouca monta, diante do que a irrelevância do indivíduo em relação à espécie no mundo objetivo se torna algo secundário, jamais primário. Enfim, o fato de o homem ser privado de valor em si é uma questáo especial de metafísica, a saber, de antropologia. Assim, é apenas do ponto de vista da vontade afirmada no indivíduo humano (para quem faz sentido valorar) que pode ter lugar algo como a defesa ou recusa do valor da vida, ou seja, a partir de uma perspectiva sempre subjetiva acerca do mundo objetivo que se lhe mostra (Moraes, 2015).

O que Schopenhauer parece pretender é que esse "olho mau" sobre a existência converta-se em remédio para sua superação ao invés de tornar-se o veneno que aponta para a amargura ou mesmo para o suicídio. A filosofia schopenhaueriana é uma filosofia da autossuficiência, do "bastar-se a si mesmo". Nesse sentido, poder-se-ia perfeitamente aplicar ao caso do "Schopenhauer pessimista" a mesmíssima ponderaçáo que Barboza (2015, p. XVI) aplica ao do "Schopenhauer irracionalista" na apresentação de sua tradução para o MVR I, escrevendo que "identificar o inimigo pode conduzir a estratégias de combate, que a própria razáo fornece quando vislumbra o todo da vida e o conhecimento conduz à redenção e negação desse próprio irracional”. O pessimismo é meio, não um princípio. Isso vale para o uso que Schopenhauer faz da palavra "pessimismo" para se referir a religióes de espírito contrário ao otimismo, pois devemos entender as religióes como meios de oferecer sentido para a existência à esmagadora maioria não talhada para a filosofia, recebendo hegemonicamente, como se náo bastasse, assentimento e justificativa da parte dos mais ilustres filósofos.

Deve-se ponderar que toda a finalidade de cada ser vivo é exclusivamente extrínseca: reside na conservação da espécie. Isso não mais que confirma objetivamente o problema teórico da não-dignidade da existência em geral. Em outras palavras, cada ser vivo nada mais é, do ponto de vista objetivo, do que mero elo na cadeia de indivíduos que se sucedem no mundo, mantendo assim a manifestação da Ideia no tempo e no espaço. Como a Vontade não tem nenhum fim determinado em si mesma - dizer o contrário significaria um 
uso ilegítimo do princípio de razão, além de nos proibir de considerá-la livre —, suas manifestações não são mais do que seu perene vir à existência, sempre renovado, em nome de que, a cada vez, a Vontade se desfaz de suas aparências táo logo se veste de uma nova. ${ }^{12}$ A "Metafísica do amor sexual" confirma no caso humano o que, nas demais espécies, se dá pelo mero instinto. Percebe-se, então, que a ilusão da paixão amorosa é um expediente intimamente ligado à generalizada ausência de fim em si mesmo, de dignidade para tudo o que existe, que engana o ser humano a respeito de seu interesse particular reconduzindo-o ao interesse da Natureza, acorrentando-o definitivamente ao mundo das aparências. Justamente por isso náo se pode dizer que haja alguma razäo para existir — apenas existimos!

Deus não precisa mais ser negado e, se o otimismo se ampara nele, cai por terra como que se se tratasse de um ídolo sobre pés de barro. Depois da crítica da razão, a denúncia da insubstancialidade do valor dos valores se revela como o segundo golpe que produz a morte de Deus.

A crítica de Schopenhauer ao teísmo, portanto, não é senão a aplicação da doutrina criticista do princípio de razão à afirmação segundo a qual, por meio do princípio de razão, seria atingível a causa primeira, individual e criadora do mundo [...]. A teodiceia emerge automaticamente do conceito de um deus criador, mas afunda com a crítica desse conceito. (Malter, 2009, p. 634)

Mas, afinal, havendo ou náo um deus, o que nos faz supor que a vida deva ter uma finalidade e, a alma, alguma dignidade, exceto pelo que antecipadamente se atribuiu ao conceito judaico-cristáo de "deus criador"? Um sentimento traiçoeiro, decerto, pois tragicamente nos move a lutar por nossos projetos pessoais, produzindo toda espécie de sofrimento e frustração pelo simples fato de compreendermos as coisas equivocadamente. Náo é por nossa causa que nenhuma vontade pode realizar-se, isto é, atingir o fim de seu querer, mas é por nós que tal fim é exigível e reiteradamente posto, de maneira que, a cada desejo, a um só tempo nos evadimos do problema e reiteramos a promessa de insucesso.

Sendo assim, que dizer de um querer impossível de satisfazer ou, mais ainda, de um náo querer impotente? Esse paradoxo é formulado por Rosset (1994, p. 106) nas seguintes palavras, no encerramento de seu livro Schopenhauer, filósofo do absurdo: "a absurdidade última da vontade schopenhaueriana consiste em que ela é incapaz de querer". Dito em outros termos: que dizer de uma vontade que náo pode realizar-se plenamente como vontade? Todavia, a Vontade já não se realiza sempre como tal ao determinar-se como um caráter? Náo corremos o risco de, contrariamente às ressalvas de Schopenhauer, confundir Vontade com desejo e intenção, cujos objetos são meras representaçôes? São estes últimos e não aquela que de fato são frustrados. Desejo e intenção estabelecem fins ilusórios ou precários, mas

\footnotetext{
${ }^{12}$ Por isso se toma a Vontade como "vontade de viver", pois assim se manifesta, não no sentido de que a vida seja o fim da Vontade. Se "toda vida é dor", pois toda vida é individuação de uma mesma Vontade que se afirma como única e a mesma em cada um, produzindo autoimpedimento, atrito e esforço sem fim no mundo, uma filosofia que aponta para a libertaçáo da dor é uma filosofia de libertaçáo da vida, único meio de a Vontade retornar à paz originária de sua unidade além do princípio de razão. Dito de outro modo, o único fim legítimo da Vontade não pode se encontrar naquilo que é finito e mundano, mas exclusivamente nela mesma. A "sabedoria de Sileno" deve ser repensada nesses termos. Como diz Malter (2009, p. 635), seria absurdo que a finalidade da vida fosse a própria vida - seu escopo é a dor. É pela experiência refletida da dor que a Vontade pode recolher-se em si mesma. Se não é para isso que a Vontade se objetiva, nem poderia sê-lo - ela somente cai por uma cegueira —, eis o que ela ganha pelo conhecimento: a possibilidade de realizar-se como liberdade no mundo. Por isso, eu emendaria o que diz Malter dizendo que náo se trataria de a dor ser um escopo da existência, mas uma faticidade cuja compreensão pode abrir um significado libertador. A Vontade, não querendo sofrer, ao encontrar no prazer um falso paliativo, encontra o verdadeiro remédio em seu próprio ser-livre originário, pelo qual nega a vida.
} 
como pode se ver frustrada uma Vontade em si mesma sem meta, um ímpeto absolutamente intransitivo?!

Há, sim, algo de fatalidade na existência considerada de um ponto de vista global. É fato que a Vontade se torne visível como matéria sob inumeráveis formas e que, sendo por inteiro em cada uma delas, avance cada uma sobre cada outra como sobre si mesma. Viver é necessariamente invadir a esfera do outro. De todo modo, semelhante diagnóstico parece apenas dizer que o mal no mundo recebe uma elucidação metafísica, náo que "o Mal" ele mesmo seja metafísico, tenha alguma substância para além da perspectiva individual que, sabemos, encerra uma ilusão. Tal ilusão, por sua vez, é ela mesma a fonte do esforço de tudo aquilo que vive cujo bloqueio é sentido imediatamente como sofrimento, bloqueio esse também fenomenal, enraizado no princípio de individuação. Assim, é legítimo ao menos não ser otimista com relação àquilo que a vida tem a oferecer. Em síntese, o mal não pertence à unidade da Vontade, mas à multiplicidade dos fenômenos. Nas palavras de Debona (2016, p. 786),

A finitude de todos os fenômenos encerra a própria condição do indivíduo como prisioneiro de si mesmo e refém do egoísmo natural alheio, domínio no qual Alles Leben ist Leiden (toda vida é sofrimento) (cf. Schopenhauer, MVR I, \$56, [2015a, p. 36o]) e do qual só se pode libertar pela renúncia da vontade de vida mediante uma renúncia de si mesmo.

O problema, todavia, é pressupor como dado aquilo que resulta do pensamento crítico. Ademais, não se pode inferir o pessimismo metafísico da premissa moral - a essência é má porque tudo é dor —, nem o contrário — tudo é dor porque a essência é má ${ }^{13}$ Antes o seguinte: o cru diagnóstico teórico da realidade da vida só encontra seu sentido na possibilidade moral (e mesmo soteriológica) que abre, mas no sentido de um indicativo, ou motivo, jamais de uma fundamentação, que não pode ser obtida por via material (casos particulares), apenas especulativa (abstração filosófica).

O olhar pessimista sobre a dor dada faz, pois, da dor, meio de sua própria superação. Somente quem sabe, como o pessimista, interpretar a dor como sinal do náo dever ser da existência individual atinge a negação da existência, que, como tal, é indubitavelmente existência de dor. (Malter, 2009, p. 634)

A doutrina do sofrimento oferece uma elucidação metafísico-cosmológica para a moral na medida em que aponta, em última instância, para o modo de ser da liberdade enquanto liberdade com relação à individualidade - esta como origem da dor e obstáculo para a compaixão —, mas não é ela mesma — a doutrina do sofrimento no mundo — uma fundamentação da moral, tampouco uma fundamentação metafísica - ao invés, é um dado empírico que Schopenhauer não se cansa de ilustrar por exaustivos exemplos. Como dado empírico, a dor é um eloquente fator a ser considerado pela Ética, certamente, e sempre

${ }^{13} \mathrm{Em}$ Sobre o fundamento da moral, Schopenhauer esforça-se, sobretudo, para provar que o fundamento da moral deve ser intuitivo, logo, oriundo de uma experiência. Náo de qualquer experiência, como de algo exterior sobre o qual se sabe, mas da experiência interna, concreta e imediata; portanto, não a partir de algo meramente imaginado, mas, sim, de um sentimento. Nesse caso, uma experiência do sentimento eventualmente ligada a uma intelecçáo que transcende o eu individual abrindo-se para todo outro. Há uma perspectiva metafísica no fundo dessa experiência, qual seja, a universalidade do sofrimento passível de conhecimento em virtude da unidade essencial da Vontade - é sempre a mesma Vontade que sofre —, mas o fundamento da moral náo é ele mesmo metafísico - é sensível. Por sua vez, a compaixão não prova a universalidade do mal, até porque há diferentes graus de superação do "véu de Maia" viabilizando diferentes graus de identificaçấo com o sofrimento alheio, que vão desde um desconforto inconsciente até a completa dissoluçáo do eu no não-eu, passando, por exemplo, pelo arrependimento. Náo obstante, pertence à natureza do "pensamento único" exigir a estrita correspondência entre metafísica e ética. 
contra o formalismo kantiano. Similarmente ao utilitarismo, mas sem de modo algum confundir-se com ele, temos aqui a proposta de redução dos males o mais possível sem, para tanto, lançar-se mão de pressupostos acerca de um bem absoluto. De todo modo, a proposta schopenhaueriana é irredutível a qualquer utilitarismo, pois este se apoia sempre no egoísmo natural, não na superação do egoísmo em geral.

Um promissor argumento seria apelar à afirmaçáo de que seria preferível que este mundo não existisse e que, se existe, é por nossa culpa. "Eis enunciado o postulado fundamental de todo pessimismo metafísico: o não ser é preferivel ao ser." (Ciracì, 2017, p. I03) Com essas palavras, de fato, Ciracì resume a aposta mais legítima no pessimismo metafísico, entendido em sentido estrito. Por que o mundo é? O niilismo parece incontornável, sobretudo porque não existe resposta para a pergunta, exceto a admissão de sua faticidade, mas, se não é um pressuposto - na verdade, tampouco um postulado no rigor do termo - , trata-se de algo que precisa ser demonstrado. Schopenhauer, todavia, não empreende essa demonstração em particular ao dizer que a vida envolve necessariamente dor, esforço e cansaço sem meta. A demonstração se dá não pela imanência, nem jamais se poderia fazê-lo, mas como implicação do que o pessimismo epistemológico nos obriga a aceitar: que não se pode admitir qualquer determinação positiva com relaçáo à coisa em si, que resta indeterminada. De imediato, como náo deixa de admitir Debona (2016, p. 788), isso soa ainda como uma contraposição a Leibniz, para quem este mundo deveria existir justamente por ser o melhor, ou seja, trata-se de mera inversão da doutrina da harmonia preestabelecida (diferente da harmonia relativa que vimos acima em Schopenhauer) e daquela que afirma ser este o melhor entre os mundos possíveis. De todo modo, a possibilidade da não existência, em última instância, consiste em um falacioso contrafatual que, segundo o próprio Schopenhauer (I877a, p. I88), caracteriza as religióes pessimistas, segundo as quais "a dor e a morte não podem jazer na ordem eterna, originária e imutável das coisas, naquilo que sob cada aspecto deve ser" 14 - de onde, contudo, viria esse "deve" (sollte)?

Fora da jurisdiçáo do princípio de razão, este mundo não pode ser senáo contingente; fora a admissão de um criador, o mundo não pode ser senão a manifestação de uma pura espontaneidade. Se o que é manifesto é uma pluralidade que não pode subsistir senão às expensas uns dos outros — verdade incontornável e lamentável por si só! —, só se pode dizer, de acordo com toda Ética digna desse nome, que melhor seria não ter de subsistir às expensas uns dos outros, produzindo dor e destruição, isto é: melhor não ser. "Não ser" é atualmente uma possibilidade impossível, se for cabível declarar tal oximoro... E quanto a, uma vez sendo, melhor morrer logo? Porque cada instante de vida individual é destruiçáo de vida alheia pela posse de sua matéria. Aquele, então, que caminha para a "morte voluntária” por inaniçáo é aquele que produz o menor mal possível, pois nele cessou, até onde vão suas forças, a luta por matéria.

À parte a dimensão especulativo-formal (abstrata) que coloca o referido contrafatual, a não existência do mundo é algo tấo absurdo como a não existência do indivíduo, sendo a imutabilidade de um e outro, em seu todo, a pedra de tropeço que se pode encontrar sob o título "pessimismo moral", que professa a incorrigibilidade do caráter com base no alheamento da vontade com relação à causalidade. Seja como for, em momento algum Schopenhauer afirma que este mundo seja na totalidade, por exemplo, destinado à destruição, tampouco que deva sê-lo, pois certamente sabe-o impossivel! O mundo como aparência de uma coisa-em-si indestrutível não pode se apagar pela autonegação da Vontade em um indivíduo, mas apenas suprimido por via ainda mais misteriosa, impossível também, pois

\footnotetext{
${ }^{14}$ Cf. Schopenhauer, 20I5b, cap. I7, p. 207; 2014a, p. 262.
} 
envolveria uma modificaçáo no seio mesmo da Vontade em geral. Muito pelo contrário, enquanto houver Vontade - e ela é, além de imutável, indestrutível - e enquanto esta se afirme haverá mundo. Para ele — já o vimos —, se não há uma harmonia preestabelecida, há um equilíbrio de forças e até mesmo uma "justiça eterna", como se a toda negação correspondesse uma afirmaçáo, uma economia de potências segundo a qual toda afirmação tem como contrapartida uma negação na mesma medida e vice-versa. "Neste mundo da aparência é táo pouco possível uma verdadeira perda quanto um verdadeiro ganho." (Schopenhauer, 20I5a, \$35, p. 2I2) Se este não é o melhor dos mundos possíveis, é ao menos aquele no qual cada coisa existente se afirma ao máximo sem aniquilar todo o resto, tal como se lê no polêmico texto "A inocência da Vontade", no qual também é dito que o "erro" que se encontra à base da existência deste mundo decorre da cegueira da Vontade originária, desprovida de conhecimento (Moraes, 2017b). Aqui já se enfraquece a polaridade com Leibniz, para quem o mundo é criado de uma vez por todas para ser tal como é, mas persiste aí uma consideraçáo mais substanciosa, não pelo simples fato de se reconhecer uma explícita oposição de Schopenhauer, não apenas a esse como a todos os otimismos encontráveis na filosofia e na religião. A falha do otimismo é a de estar cego à realidade, não parecendo necessário lhe opor a tese contraditória — reitero — , apenas tirar-lhe a venda dos olhos - este parece ser o propósito do "realismo áspero", produtor do diagnóstico "pessimista". Nietzsche demonstra havê-lo compreendido bem:

A enorme bravura e sabedoria de Kant e de Schopenhauer conquistaram a vitória mais difícil, a vitória sobre o otimismo oculto na essência da lógica, que é, por sua vez, o substrato de nossa cultura. Se esse otimismo, amparado nas aterne veritatis, para ele indiscutíveis, acreditou na cognoscibilidade e na sondabilidade de todos os enigmas do mundo e tratou o espaço, o tempo e a causalidade como leis totalmente incondicionais de validade universalíssima, Kant revelou que elas, propriamente, serviam apenas para elevar o mero fenômeno, obra de Maia, à realidade única e suprema [...]. Imaginemos uma geraçáo a crescer com esse destemor no olhar, com esse heroico pendor para o descomunal, imaginemos o passo arrojado desses matadores de dragóes, a orgulhosa temeridade com que dáo as coisas a todas as doutrinas da fraqueza pregadas pelo otimismo [...]. (Nietzsche, I992, \$I8, p. IIO-III)

\section{O diagnóstico pessimista}

Como se sabe, as qualificaçôes "otimista" e "pessimista" são contrapostas intensamente no capítulo 17 do MVR II em referência às espécies de religiäo. ${ }^{15}$ É certo que Schopenhauer dialoga elogiosamente com as religiốes ditas por ele mesmo "pessimistas", mas não terá algum significado que não o faça com relação a doutrinas filosóficas quaisquer? Náo seria o caso de as religiôes serem assim classificadas por aquilo em que se baseiam e prometem? Toda religiáo promete algo que implica uma certa atitude perante o divino, alguma espécie de beatitude, mas duas coisas não cabem à filosofia, apenas àquilo dirigido ao homem vulgar: prometer e oferecer falsos (ou fictícios) fundamentos. Filosofias otimistas se baseiam em falsas teodiceias, a partir das quais fazem falsas promessas. No caso das filosofias otimistas cristâs, deixam de lado o pessimismo original segundo o qual o mundo em que vivemos é resultante de uma culpa, de um erro, que tem no homem sua origem, valorizando em seu lugar como elemento soteriológico a promessa de vida herdada do judaísmo, não a recusa da vida ensinada por Jesus. Vale arriscar que as religióes estáo para a opiniáo como a autêntica filosofia está para a verdade - por isso mesmo não é legítima uma filosofia otimista, pois o otimismo é infundado (seja metafísica, seja empiricamente) e em desacordo com a

\footnotetext{
${ }^{15}$ V. p. ex. o verbete sobre o pessimismo em Cartwright (2005, p. I24-I26).
} 
verdade legada pela crítica da razão, ferindo seus limites. Por sua vez, à verdade não cabe atribuir valor - ela mesma é seu próprio valor —, ao passo que as religiōes, enquanto opinióes, recebem da verdade o seu valor. Como filósofo, Schopenhauer julga as religióes à luz da verdade, por isso aplicando a algumas o epíteto "pessimista", não a sua filosofia ou a qualquer outra, senão "analogicamente", ao passo que a qualificaçáo inversa pesa como denúncia de uma fé disfarçada. Desta feita, opiniōes más sobre a existência, a desvalorização pessimista, têm a verdade a seu favor. A filosofia que náo decai no interesse vulgar simplesmente paira acima dos valores, para além do bem e do mal. Nesse sentido, a filosofia só pode apontar para possibilidades, náo lhe cabendo prometer ou garantir promessas.

Todo o exposto aqui merece uma síntese, isto é, um "pessimismo" cujo qualificativo possa ser aplicado ao conjunto das perspectivas. Esse qualificativo pode ser encontrado no texto de Wicks: pessimismo antropomórfico. ${ }^{16}$ Cabe de imediato chamar a atenção do leitor para a irredutibilidade desse pessimismo antropomórfico ao antropológico - este concernente à natureza humana em particular -, do mesmo modo que, por "antropomórfico", não se deve entender a concepção segundo a qual o homem é o centro do mundo (antropocentrismo). Como vimos e é bem sabido, o ser humano não é essencialmente "melhor" do que nada no universo; sua relativa perfeiçáo diz respeito tão somente ao fato de nele, mediante a aquisição da autoconsciência, tornar-se possível o conhecimento da Vontade por ela mesma como indivíduo. Logo, antropomórfico remete à tese crítica segundo a qual o mundo é representaçáo do intelecto humano, assumindo suas configuraçóes, assim como esse mesmo mundo é tomado como Vontade segundo analogia com a experiência interna do querer humano. Em suma, antropomórfico é o mundo conformado segundo o princípio de razão, não aquele que tem o homem como finalidade da Criação. Schopenhauer, todavia, disputa na arena do otimismo fundado no teísmo antropomórfico (e antropocêntrico). Nesse sentido, não se trata apenas de dizer que o pessimismo diga respeito exclusivamente ao mundo humano ou ao que lhe concerne. Trata-se de dizer que o "péssimo" pertence ao modo como o mundo é objetivamente dado, segundo o princípio de razão, ao sujeito humano que conhece, cujo conhecimento é imbuído de valores, interesses, expectativas etc. O mundo como um todo, todos os seus possíveis atributos inclusos, recebe do homem sua aparência refletida - não seu valor intrínseco, como no antropocentrismo -, sendo o que é por ele e para ele, bem como nele, no intelecto que representa, na vontade que quer. Para Wicks (2017), com grifos meus,

Isso marca a origem do afamado pessimismo de Schopenhauer: ele afirma que, enquanto indivíduos, somos os desafortunados produtos de nossa própria criaçáo epistemológica e que, no mundo de aparências que estruturamos, estamos destinados a lutar com outros indivíduos e a querer mais do que um dia possamos obter. $\mathrm{Na}$ visão de Schopenhauer, o mundo quotidiano é essencialmente violento e frustrante; é um mundo que nunca se resolverá em uma condição de maior tranquilidade enquanto nossa consciência permanecer no nivel de aplicaçấo do princípio de razão suficiente e sua quádruplice raiz.

\footnotetext{
${ }^{16}$ V. tb. Malter, 2009, p. 633: "a hipótese de uma origem do mundo individual, racional e dotada de vontade [é] concebida em analogia com o homem". Acrescento, por sua vez, de acordo com Wicks, que o sofrimento no mundo também é concebido e mesmo sentido em analogia com o homem, sendo expressão da vontade no homem. Nas palavras de Wicks (20I7), relativamente ao modo objetivo de consideraçấo: "É o ser humano que, em seu grande esforço para tudo conhecer, objetifica uma aparência para si que envolve a fragmentaçáo da Vontade e sua ruptura em uma compreensiva gama de indivíduos”. Conforme já dissera Kant — que criamos as leis da natureza —, Schopenhauer — prossegue Wicks — insiste que "nós criamos o violento estado de natureza”, já que essa individuaçáo que impomos às coisas violenta a si mesma.
} 
[...] a violência que uma pessoa experimenta é proporcional ao grau de individuação e objetivação de sua consciência. Sua visão é a de que com menor individuação e objetivação há menos conflito, menos dor e mais paz.

A visão pessimista de Schopenhauer sobre o mundo pode ser tomada como sendo fundada na distinçáo sujeito-objeto, i.e., na raiz geral do princípio de razão suficiente.

Assim, uma vez mais: a culpa é nossa, inteiramente nossa. Aqui, como nunca, parece valer a alegoria do Pecado Original, estimada por Schopenhauer como aquilo que há de valor no Antigo Testamento: o primeiro homem, ao adquirir o conhecimento, tornou-se culpado pela dor sem fim, pelo suor e pelo cansaço de toda a Natureza em luta pela conservação em um mundo cuja felicidade, satisfação, ingenuidade, pureza, paz e imortalidade estariam desde então e para sempre perdidas, a não ser — emendará o Novo Testamento - pela decidida e livre negação desse pecado que é o querer viver, a correção do erro inato cravado em cada coraçáo mediante a qual a Vontade retorna à paz originária e eterna de sua liberdade essencial.

A visão metafísica, na medida em que o permitem os limites epistemológicos e o exige a possibilidade moral em vista do triste quadro antropológico, sendo imanente, é marcada por um caráter a posteriori. Cabe aqui, como nunca, elucidar que o pessimismo crítico, de alcance transcendental, é um diagnóstico. Um "diagnóstico" significa um conhecimento mediado por sintomas, ou seja, pelas manifestaçóes de algo que se pretende conhecer. Assim, é por intermédio da configuraçáo antropomórfica do mundo, cujos sintomas são os únicos disponíveis, que se elabora o diagnóstico que, como tal, não apenas descreve o sintoma, mas busca identificar de que o sintoma é sintoma, qual a "doença" a ser tratada, e a resposta é: o erro da insistência no querer viver a todo custo sem promessa de saldo positivo. Assim, o “pessimismo pragmático" (Debona, 20I6), se assim se quiser chamá-lo, tem o seu lugar, amparado pela retórica do péssimo, a "lógica do pior", lembrando a expressão de Clément Rosset. De todo modo, esse remédio supera a valoraçáo otimista ou pessimista, resolvendose no que o próprio Schopenhauer disse em sua obra magna. O realismo áspero — atitude correta perante as aparências, irredutível em si mesmo a todo pessimismo.

\section{Referências bibliográficas}

Barboza, J. (2015). “Um livro que embriaga." In: Schopenhauer, A. O mundo como vontade e como representaçâo: tomo I. Sáo Paulo: UNESP, pp. XIII-XXIV.

Cacciola, M. L. M. e O. (1994). Schopenhauer e a questão do dogmatismo. São Paulo: EDUSP.

Cartwright, D. E. (2005). Historical dictionary of Schopenhauer's philosophy. Lanham (Maryland): Scarecrow.

Ciracì, F. (20I7). "Metafisiche del nulla: Schopenhauer, i suoi discepoli e l'inconsistenza del mondo", Consecutio Rerum: rivista critica della postmodernità. Roma, v. I, n. 2, pp. 99-II4. Disponível em: < http://www.consecutio.org/wp-content/uploads/2017/o4/ciraci.pdf >. Acesso em: 25 ago. 2018.

Debona, V. (2016). "Pessimismo e eudemonologia: Schopenhauer entre pessimismo metafísico e pessimismo pragmático", Kriterion, v. 57, n. 135, pp. 78I-802. Disponível em: < http://www.scielo.br/pdf/kr/v57ni35/oI00-5I2X-kr-57-I35-078I.pdf >. Acesso em: 25 ago. 2018.

Fazio, D. M. (2007). "La 'scuola' di Schopenhauer: per la storia di un concetto.” In: Ciracì, F.; Fazio, D. M.; Pedrocchi, F. (Org.). Arthur Schopenhauer e la sua scuola. Lecce: Pensa MultiMedia, pp. 35-76.

Fazio, D. M. (2009). "La scuola di Schopenhauer: i contesti." In: Fazio, D. M.; Koßler, M.; Lütkehaus, L. (Org.). La scuola di Schopenhauer: testi e contesti. Lecce: Pensa MultiMedia, pp. I3-2I2.

Fazio, D. M. (20I4). "La controversia sul pessimismo.” In: Eco, U.; Fedriga, R. (Org.). Storia della Filosofia: 3 - Ottocento e Novecento. Roma: Laterza, pp. 94-98. 
Fazio, D. M. (2018). "La scuola di Schopenhauer attraverso il carteggio con i discepoli." In: Schopenhauer, A. Carteggio con i discepoli. Ed. Trad. Domenico M. Fazio. Lecce: Pensa MultiMedia, pp. I-I37.

Japiassú, H.; Marcondes, D. (1996). “Otimismo/pessimismo.” In: Japiassú, H.; Marcondes, D. Dicionário básico de filosofia. 3. ed. rev. ampl. Rio de Janeiro: J. Zahar, pp. 203-204.

Leibniz, G. W. (2004). Discurso de metafísica e outros textos. São Paulo: M. Fontes.

Lindner, E. O. (2009) "La filosofia tedesca all'estero." (Traduçáo anotada do artigo de John Oxenford, "Iconoclasm in German philosophy"). In: Fazio, D. M.; Koßler, M.; Lütkehaus, L. (Org.). La scuola di Schopenhauer: testi e contesti. Lecce: Pensa MultiMedia, pp. 263-289.

Malter, R. (2009) "Il pessimismo: un concetto critico.” In: Fazio, D. M.; Koßler, M.; Lütkehaus, L. (Org.). La scuola di Schopenhauer: testi e contesti. Lecce: Pensa MultiMedia, pp. 624-635.

Moraes, D. (20II). Liberdade e negação da vontade: análise do ser-livre como representação e na angústia. Tese (Doutorado em Filosofia) - Universidade Federal do Rio Grande do Norte, Natal.

Moraes, D. (2015). "Mefistófeles e o mundo como vontade: os tipos afirmador e negador, otimista e pessimista, no Fausto, de Goethe". In: Carvalho, M., Danowski, D., Salviano, J. O. S. (Org.). Temas de Filosofia. São Paulo: ANPOF, p. I60-175. Disponível em: $<$ http://www.anpof.org/portal/images/Colecao_XVI_Encontro_ANPOF/Temas_de_Filosofia.pdf>. Acesso em: 25 ago. 2018.

Moraes, D. (2017a). "O pessimismo moral schopenhaueriano: origem, significado e alcance". Ethic@: revista internacional de filosofia moral, v.16, n. 2, nov. 20I7a, p. 347-374. Disponível em: < https://periodicos.ufsc.br/index.php/ethic/article/view/1677-2954.20I7vi6n2p347 >. Acesso em: 25 ago. 2018.

Moraes, D. (2017b). "A inocência da Vontade.” In: Correia, A.; Debona, V.; Tassinari, R. (Org.). Hegel e Schopenhauer. São Paulo: ANPOF, pp. 276-287. Disponível em: < http://www.anpof.org/portal/images/CAPAS_20I7/hegelschopenhauer-FINAL.pdf >. Acesso em: 25 ago. 2018.

Moraes, D. (20I8). "Consideraçôes preliminares sobre o modo de ser da ideia na metafísica de Schopenhauer". Problemata: revista internacional de filosofia, v. 9, n. I, p. 267-302. Disponível em: < http://www.periodicos.ufpb.br/ojs2/index.php/problemata/article/view/38727 >. Acesso em: 25 ago. 2018.

Nietzsche, F. (1992). O nascimento da tragédia, ou helenismo e pessimismo. Trad. J. Guinsburg. Sáo Paulo: Companhia das Letras.

Rosset, C. (1994). Schopenhauer, philosophe de l'absurde. 2. ed. Paris: PUF.

Schopenhauer, A. (1877a). Sämtliche Werke. V. III. Ed. Julius Frauenstaedt. Leipzig: Brockhaus.

Schopenhauer, A. (1877b). Sämtliche Werke. Vol. IV. Ed. Julius Frauenstaedt. Leipzig: Brockhaus.

Schopenhauer, A. (200Ia). Sobre o fundamento da moral. Pref. Alain Roger. Trad. Maria Lúcia Mello Oliveira Cacciola. São Paulo: M. Fontes.

Schopenhauer, A. (200Ib). Schopenhauer im Kontext: Werkausgabe I. Berlin: Karsten Worm InfoSoftWare, I CD-ROM.

Schopenhauer, A. (20I4a). O mundo como vontade e representação: tomo II - complementos. Trad. Eduardo Ribeiro da Fonseca. Curitiba: UFPR, v. I.

Schopenhauer, A. (20I4b). O mundo como vontade e representação: tomo II - complementos. Trad. Eduardo Ribeiro da Fonseca. Curitiba: UFPR, v. 2.

Schopenhauer, A. (20I5a). O mundo como vontade e como representação: tomo I. Trad. Jair Barboza. São Paulo: UNESP.

Schopenhauer, A. (20I5b). O mundo como vontade e como representação: tomo II. Trad. Jair Barboza. São Paulo: UNESP.

Schopenhauer, A. (2018). Carteggio con i discepoli. Ed. Trad. Domenico M. Fazio. Lecce: Pensa MultiMedia.

Wicks, R. "Arthur Schopenhauer." In: Zalta, E. N. (Ed.). The Stanford Encyclopedia of Philosophy. Summer 2017 Edition. Disponível em: < https://plato.stanford.edu/archives/sum2017/entries/schopenhauer/ >. Acesso em: 25 ago. 2018. 